\title{
CHARACTERIZATION OF THE ACOUSTIC OUTPUT OF THERAPEUTIC ULTRASOUND EQUIPMENT
}

\section{G van der Merwe (MSc Physics Stellenbosch) \\ N Bhagwandin (MSc Physics Natal) JE van der Spuy B Eng Hons Stellenbosch) $P$ R le Roux (PhD Physics Cape Town). Directorate of Radiation Control}

\begin{abstract}
SUMMARY
The safety and efficacy of ultrasound therapy may be compromised if the output from therapy transducers differs considerably from the indicated value. Although the total power output of a transducer can be easily measured using a pressure balance, it is also important to know how this energy is distributed through space. By "using a hydrophone scanning technique, beam profiles of the energy distribution can be obtained. From the beam profiles various parameters such a the effective radiating area (ERA) and the beam non-uniformity ratio (BNR) can be determined. Since the spatial-average intensity selected for treatment is a ratio of the emitted ultrasound power and the effective radiating area, it is essential to be able to measure parameters like the effective radiating area. In this study ERA and BNR measurements for commercially available devices were performed with a hydrophone scanning technique.
\end{abstract}

\section{OPSOMMING}

Die effektiwiteit en veiligheid van ultraklankterapie kan bevraagteken word indien die lewering vanaf terapie-omsetters betekenisvol afwyk vanaf die aangeduide waarde. Ahoewel die totale drywingslewering vanaf ' $n$ omsetter maklik gemeet kan word met behulp van ' $n$ drukbalans, is dit ook belangrik om te weet hoe die energie ruimtelik versprei is. Bundelprofiele van die energieverspreiding kan verkry word deur gebruik te maak van 'n hidrofoon-aftastings-tegniek. Vanaf die bundelprofiele kan verskeie parameters soos die effektiewe stralingsarea (ESA) en die nie-uniformiteitsverhouding van die bundel (BNV) verkry word. Aangesien die ruimtelik-gemiddelde intensiteit, wat gewoonlik as 'n behandelingsparameter gekies word, die verhouding tussen die uitgestraalde drywing en die effektiewe stralingsarea is, is dit van belang om parameters soos die effektiewe stralingsarea to kan bepaal. In hierdie studie is van 'n hidrofoon-aftastings tegniek gebruik gemaak om ESA en BNV metings van kommersiëel beskikbare terapie toestelle te verkry.

\section{DEFINITIONS}

Effective radiating area (ERA) ${ }^{1}$ means the area of the effective radiating surface that consists of all points at which the ultrasonic 
intensity is equal to or greater than $5 \%$ of the maximum spatial ultrasonic intensity at the effective radiating surface, expressed in $\mathrm{cm}^{2}$.

Beam non-uniformity ratio (BNR) ${ }^{1}$ means the ratio of the highest intensity (spatial peak) in the ultrasound field to the average intensity.

\section{INTRODUCTION}

Of all the techniques available to measure and characterize the acoustic output of ultrasound therapy equipment, the determination of total power with a radiation pressure balance together with the spatial and temporal field characterization using a calibrated hydrophone ${ }^{2,3}$ have found most widespread use and acceptance. These two techniques permit the measurement of most parameters accepted to be of importance in ultrasound therapy applications.

The principle of the radiation pressure balance is the measurement of the force produced on a target intercepting the whole ultrasound beam. The force may be related to the total power in the ultrasound beam. Various designs of ultrasonic pressure balances are widely used to assess the accuracy of the total output power of ultrasound therapy devices.

However, major shortcoming in the use of pressure balances is the fact that no information is gained on the distribution of ultrasound throughout the acoustic field. The determination of the distribution of acoustic energy in both space and time is important in the assessment of parameters like the effective radiating area and the beam non-uniformity ratio. For the measurement of these parameters a beam plot system is used. In essence, the system consists of a water tank into which the ultrasound beam radiates and a calibrated measuring hydrophone (underwater microphone) scanning the beam by mechanical means.

A hydrophone is a device that produces an electrical signal in response to an applied acoustic field. The sensitive element of the hydrophone is usually a small piezoelectric element and the electrical voltage developed is related to the acoustic pressure at the element. By scanning a hydrophone across an ultrasound field, an indication of the distribution of the acoustic pressure across the field can be obtained (a beam profile). In this study these beam profiles are used to determine:

- The Effective Radiating Area (ERA); and

- The Beam Non-uniformity Ratio (BNR).

\section{MEASUREMENT APPARATUS}

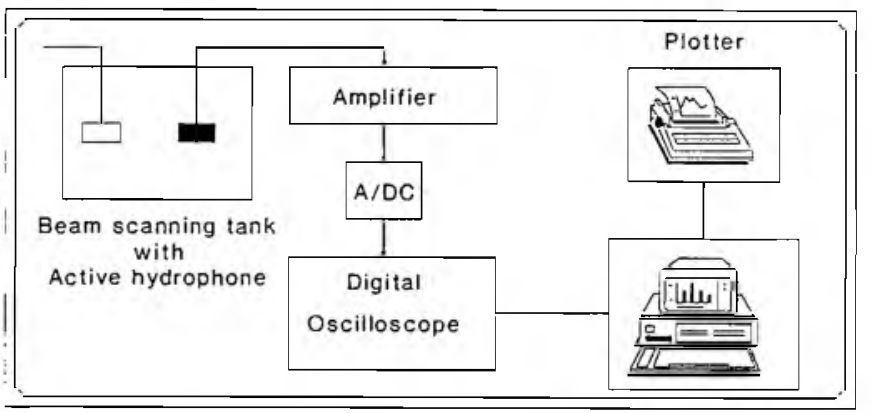

Figure 1: Schematic and block diagram of the measurement apparatus

The measurement apparatus at the Directorate Radiation Control is shown schematically in Fig. 1. The ultrasound scans are done in a tank, $60 \times 26 \times 26 \mathrm{~cm}$ to which fixtures are attached for mounting hydrophones and transducers. The hydrophone mount is attached to a gear system which provides $x, y$ and $z$ translation. The hydrophone can also be rotated about two axes. Scans used for measurements consist of a two-dimensional array of data accumulated in a raster fashion in the $x, y$ plane, at a fixed $z$-distance from the transducer face. The scan size and step size are variable. Typical step sizes are between $1 \mathrm{~mm}$ and $2 \mathrm{~mm}$ and typical scans consist of approximately 2000 data points.
All measurements are made in tap water with a nominal $0.5 \mathrm{~mm}$ diameter Medisonics (Medisonics (UK) Ltd., Haslemere, Surrey, UK) hydrophone, which has a frequency range between $200 \mathrm{kHz}$ and $15 \mathrm{MHz}$.

\section{RESULTS}

\section{Effective Radiating Area (ERA)}

The measurement of the effective radiating area (ERA) of ultrasonic physiotherapy devices is a crucial facet of their calibration. The spatial averaged intensity, formulated as the ratio of the ultrasonic power to the effective radiating area (ERA), is one of the fundamental treatment parameters chosen in ultrasound therapy. Temperature rises in tissue, which play a considerable role in ultrasound therapy, are proportional to this quantity ${ }^{4}$. The intensity levels for therapy are also in the range where adverse biological effects have been observed. Problems can therefore arise with both the safety and efficacy of treatments if the spatial average intensities deviate considerably from their indicated values.

Some of the difficulties encountered with ERA measurements have been discussed elsewhere 5 . A sample plot of a two-dimensional raster scan, obtained with the hydrophone scanning technique to determine the ERA, is shown in Fig. 2.

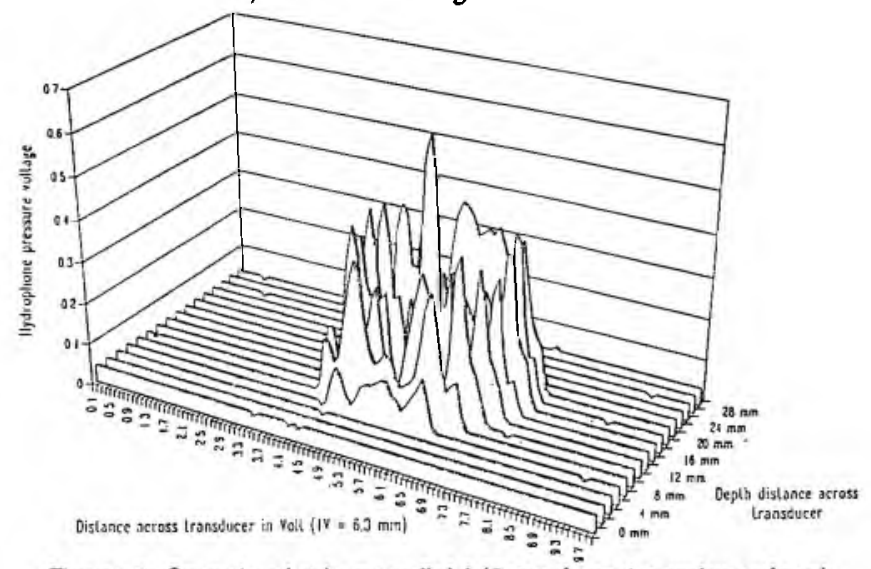

Figure 2: Sample plot in near field ( $5 \mathrm{~mm}$ from transducer face)

\section{Beam Non-uniformity Ratio (BNR)}

The ultrasonic beam distribution produced by a therapeutic transducer is nonuniform in nature. The intensity within the ultrasonic beam varies; that is, some points are higher or lower than others. Thus, when an ultrasonic therapy unit is set to produce a particular intensity, say $2 \mathrm{~W} / \mathrm{cm}^{2}$, there will be places in the beam where the intensity is actually higher than the indicated value. A numerical indicator of this non-uniformity is provided by the beam non-uniformity ratio, abbreviated BNR.

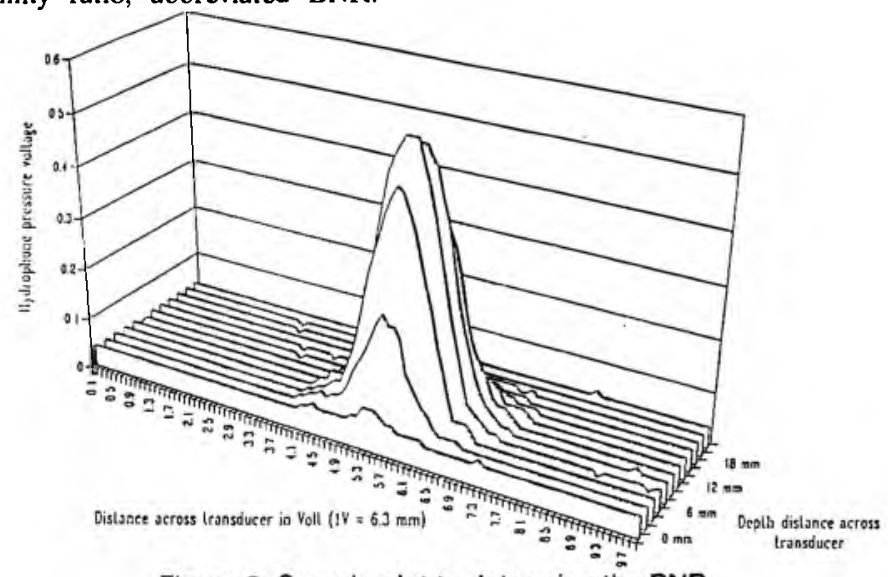

Figure 3: Sample plot to determine the BNR

The BNR is simply the quotient of the highest intensity in the field to the average intensity indicated on the meter. For example, if the 


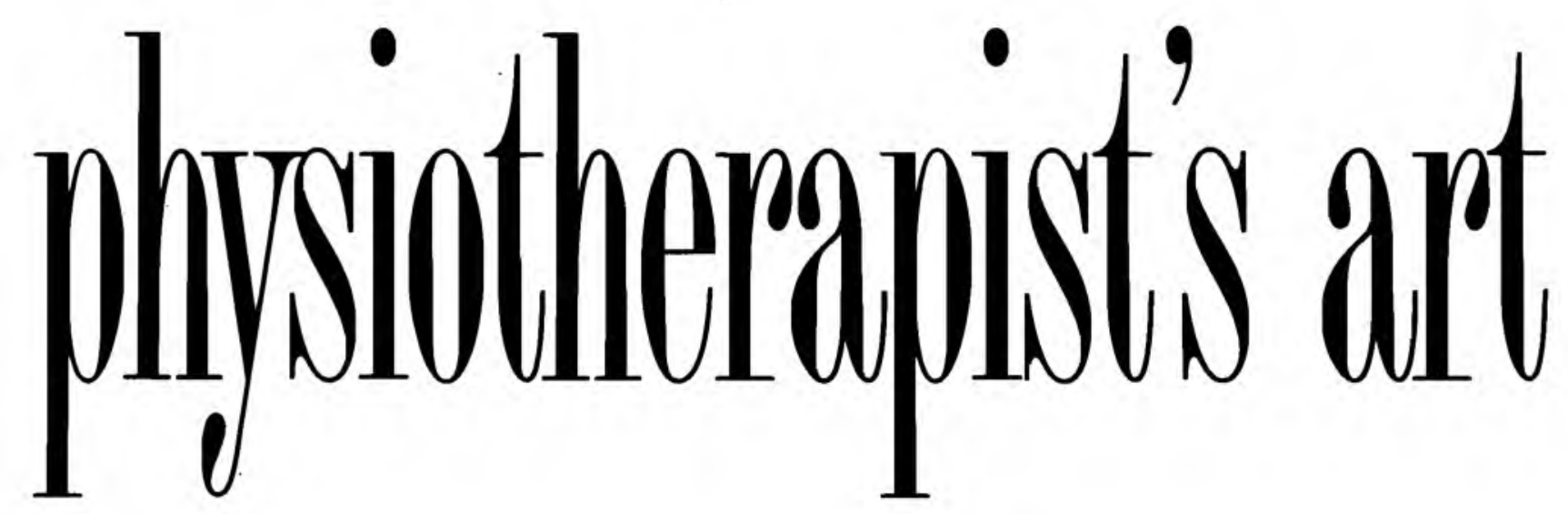

\section{New-Atrovent Inhalant Solution}

\section{Unit Dose Vials}

- Added always to your standard $B_{2}$ solution

- Precise dose every time

- Simple and convenient

- Preservative-free

\section{Bisolvon $^{\circledR}$ solution}

- Reduces bronchial and nasal secretion viscosity

- Facilitates mucocilliary transport and expectoration

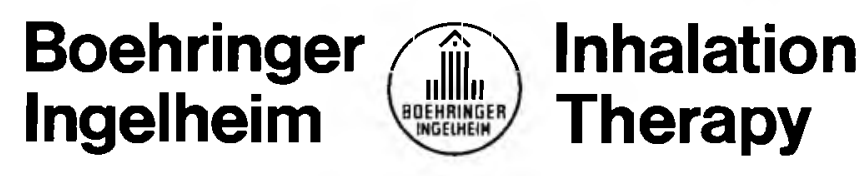

\section{Creating a better climate for your patients}


BNR is 4.0 and the unit is set for an indicated intensity of $2.0 \mathrm{~W} / \mathrm{cm}^{2}$, then at some point in the beam the intensity is actually $8.0 \mathrm{~W} / \mathrm{cm}^{2}$. By looking at the intensity distribution of an ultrasound beam, some qualitative information about where the highest intensity is located can be acquired. The BNR is a useful indicator of the degree of non-uniformity. It is therefore vital in the therapeutic application of ultrasound that the applicator (soundhead) be moved continuously over the area being treated as a result of non-uniformity of the beam. This causes the energy distribution to be more uniform and thus prevents high temperature buildup in tissues. A sample plot of a two-dimensional raster scan, obtained with the hydrophone scanning technique to determine the BNR, is shown in Fig. 3.

\section{DISCUSSION}

Measurements were made on 6 ultrasonic beams, one from each commercially available ultrasonic physiotherapy device inspected. It is recommended that the measured effective radiating area (ERA) should be within $20 \%$ of the labelled value ${ }^{6}$. The device code, operating frequency, measured ERA and manufacturer's rated values are given in Table 1 . For one of the six devices, the ERA was not within $20 \%$ of the rated value. For devices $C$ and $D$ the rated value of the manufacturer was not known.

\begin{tabular}{|c|c|c|c|c|c|}
\hline DEVIE CODE & $\begin{array}{c}\text { FREQUENCY } \\
\left(\begin{array}{c}\text { (MHZ) } \\
\text { A }\end{array}\right.\end{array}$ & $\begin{array}{c}\text { MEASURED } \\
\text { ERA (CM })\end{array}$ & $\begin{array}{c}\text { RATEDERA } \\
\left(\text { (CM }^{2}\right)\end{array}$ & $\begin{array}{c}\text { PERCENTAGE } \\
\text { DEVIATON }\end{array}$ & BNR \\
\hline B & 3.1 & 3.8 & 4.4 & 13 & 8.16 \\
\hline C & 1.1 & 3.25 & unknom & - & 7.72 \\
\hline D & 1.1 & 3.25 & unknown & - & 7.84 \\
\hline E & 1.1 & 3.05 & 5 & 64 & 8.96 \\
\hline F & 0.87 & 3.5 & 4 & 14 & 8.06 \\
\hline
\end{tabular}

Table I: Results of measurements made on 6 ultrasonic beams

The quantity termed \% deviation is defined as

$\%$ Deviation $=\left[\left(\right.\right.$ ERA $_{m}-$ ERAI $\left.) / E R A m\right] \times 100$

where ERAm is the value of the ERA as calculated from the measured raster scan and ERAI is the ERA value indicated by the manufacturer.

Various international safety guidelines recommend an upper limit to radiated ultrasound energy to protect the patient against adverse biological effects. The World Health Organisation ${ }^{7}$ (WHO) limits the spatial average intensity to a maximum of $3 \mathrm{~W} / \mathrm{cm}^{2}$, while the International Electrotechnical Commission ${ }^{8}$ states the same limit of $3 \mathrm{~W} / \mathrm{cm}^{2}$ for both the continuous wave mode and the pulse wave mode. However, a safety aspect that is not considered in these limits, is the occurrence of high spatial peak intensities within the beam. High spatial peak intensities (also known as "hot spots") may cause damage to the patient's tissues and should therefore be avoided. As discussed earlier, these hot spots are usually quantified by the beam non-uniformity ratio (BNR). Although most safety standards do not specity a limit on the BNR, the TNO Medical Technology Unit of the Netherlands ${ }^{9}$ used a BNR ratio of 8 as a limit in a survey done on ultrasound therapy devices. This value is used as a guideline in the current study.

The BNR values for the six ultrasound beams under study are listed in Table 1. Of these, one had a BNR ratio above 8 .

Summarizing the measurement of the ERA and BNR, it may be concluded that only two of the units comply with the requirements set for safety and accuracy, that is, a measured ERA deviating less than $20 \%$ from the labelled ERA, and a moderate BNR. No conclusion could be made on two further units due to a lack of manufacturer's data, while two units did not comply with the requirements set. This result is in accordance with results from similar investigations abroad $9,10.11$.

Quality control and acceptance testing of equipment, dosimetry and fundamental studies of ultrasonic techniques all require the measurement of acoustic output. Hence, the measurement and specification of the acoustic output of medical ultrasonic equipment is an area of growing interest and concern.

\section{REFERENCES}

1. Food and Drug Administration, Department of Health and Human Services, United States of America. Performance Standands for Sonic, Infrasonic and Ultrasonic Radiation Emitting Products Part 1050. Code of Federal Regulations 21 Pars 800 to 1299, 1985:365-369.

2. Preston RC. Measurement and characterization of the acoustic output of medical ultrasonic equipment Part 2. Med \& Biol Eng \& Comput 1986;24:225-234.

3. Harris GR. A discussion of procedures for ultrasonic intensity and power calculations from miniature hydrophone measurements. Ulerasound in Medicine and Biology 1985;11(6):803-817.

4. Nyborg WL Interaction mechanisms:Heating. In Repacholi MH, Grandolfo M, Rindi A, eds. Ultrasound:Medical applications, biological effects and hazand potential. New York:Plenum Press; 1987:73-84.

5. Bly SHP, Hussey RG, Kingsley JP et al. Sensitivity of effective radiating area measurement for therapeutic ultrasound transducers to variations in tydrophone scanning technique. Health Physics 1989;57(4):637-643.

6. Canadian Government Publishing Centre. Standard for Ultrasound Therapy Devices. (MICanada Gazette Part II 1984.

7. World Health Organisation. Ultrasound. Environmental Health Criteria22 Geneva, 1982.

8. International Electrotechnical Commission. Medical Electrical Equipment Pant 2: Particular Requirements for the Safety of Ultrasonic Therapy Equipment. Publication 601-2-51984.

9. Hekkenburg RT, Oosterbaan WA, Van Beekum WT. Evaluation of Ultrasound Therapy Devices. Phusiotherapy 1986;72(8):390-394.

10. Sieward HF, Harris GR, Herman BA. Survey of use and performance of ultrasonic thera py equipment in Pinelles County. Physical Therapy 1974;54(7):707-715.

11. Repacholi MH, Benwell DA. Using surveys of ultrasound therapy devices to draft performance standards. Health Physics 1979;36:679-686.

\section{PHYSIO FORUM IN 1992}

\section{FORUM DEADLINES}

In 1992 Physio Forum will continue to be published 8 times a year, in January, March, April, June, July, September, October and December. However, due to pressure of work, and to allow a margin for last-minute submissions, the schedule for deadlines has been slightly altered.

Please note that the deadline is $12 \mathrm{~h} 30$ on the days listed below, and late submissions should be cleared by telephone. We cannot guarantee the publication of any late contribution.

$\begin{array}{ll}\text { ISSUE } & \text { DEADLINE } \\ \text { March } & 5 \text { February } \\ \text { April } & 4 \text { March } \\ \text { June } & 29 \text { April } \\ \text { July } & 3 \text { June } \\ \text { September } & 5 \text { August } \\ \text { October } & 2 \text { September } \\ \text { December } & 4 \text { November } \\ \text { January } & 2 \text { December } \\ \text { It would be advisable to keep a copy of these dates in the } \\ \end{array}$

